\title{
Landowner willingness to participate in a Texas brush reduction program
}

\author{
URS P. KREUTER, MARK R. TAYS, AND J. RICHARD CONNER
}

Authors are Assistant Professor, Department of Rangeland Ecology and Management, Texas A\&M University, College Station, Tex. 77843-2126; County Executive Director, USDA-Farm Service Agency, Austin, Texas; Professor, Department of Agricultural Economics, Texas A\&M University, College Station, Tex.

\section{Abstract}

Because most of Texas consists of privately owned land and the amount of brush cover on rangelands may affect off-site water yields, there has been increasing interest in publicly funded brush clearing programs aimed at increasing water yield. The Pedernales River was selected as 1 of 8 watersheds to determine the feasibility of implementing such a program. A survey questionnaire was mailed to $\mathbf{7 2 0}$ landowners in Blanco and Gillespie County (containing most of the Pedernales watershed) in June 2000 to identify factors that influence their interest in participating in a brush reduction program. The sample consisted of equal numbers of landowners with 4-20, 21-202, and > 202 ha of land. Fifty eight percent of the survey participants responded, $82 \%$ of whom answered questions about their willingness to enroll at least part of their land in a brush reduction program. Property size and income from wildlife were found to be significant positive determinants and level of satisfaction with brush a significant negative determinant of respondents' willingness to enroll. To optimize public investments, it may be preferable to maximize the area enrolled in a brush removal program by targeting larger landowners who appear to be willing to enroll larger portions of their land without requiring compensation that exceeds their net cost of enrollment. Because land in the Edwards Plateau is being subdivided and purchased by people who do not depend on landbased income and who may be more tolerant of brush, public funds required to encourage landowner participation may increase over time.

Key Words: Brush management, canopy cover, cost sharing, landowner perceptions, mail survey, rangeland water yields

The population of Texas is expected to grow from about 20 million to more than 36 million by 2050 (TWDB 1997). Much of this growth will occur along Highway I-35 that runs through San Antonio, the population of which grew $25.2 \%$ from 1990 to 1998 (SAEDF 1999), and the Austin/San Marcos area, which experienced a $47.7 \%$ population increase between 1990 and 2000 (TSDC 2000). Because of its close proximity to Austin and San Antonio and its high aesthetic appeal, the Edwards Plateau is facing similar population pressure with a projected $88 \%$ increase from 1995 to 2030 (Conner and James 1996). Two effects of

The research reported in this publication was funded under the Texas State Soil and Water Conservation Board project \# 403138. The voluntary participation of Texas landowners in the mail survey is greatly appreciated, as are the constructive comments made by Mitch McClaran and 3 anonymous reviewers.

Manuscript accepted 25 Aug. 03.

\section{Resumen}

Debida a que la mayor parte de Texas consiste de terrenos privados y la cantidad de cobertura de arbustos en los pastizales puede afectar la producción de agua en el sitio ha habido un creciente interés por los programas de aclareo de arbustos financiados públicamente enfocados a aumentar el rendimiento de agua. El Río Pedernales se seleccionó como 1 de 8 cuencas hidrológicas para determinar la factibilidad de implementar tal programa. En Junio del 2000 se envió por correo un cuestionario a 720 propietarios de terrenos en los condados de Blanco y Gillespie (que contienen la mayor parte de la cuenca hidrológica Pedernales) para identificar los factores que influyen en su interés para participar en el programa de reducción de arbustos. La muestra consistió de igual número de propietarios de terrenos de 4-20, 21-202 y $>$ 202 ha de tierra. El 58\% de los participantes en la encuesta respondieron el cuestionario, $82 \%$ de los cuales contestaron las preguntas respecto a su disponibilidad para inscribir al menos parte de su tierra en un programa de reducción de arbustos. Se encontró que el tamaño de la propiedad y el ingreso por la fauna silvestre son determinantes positivos significativos y el nivel de satisfacción con los arbustos como un determinante negativo de la disponibilidad de los que respondieron para inscribir sus terrenos. Para optimizar las inversiones públicas puede ser preferible maximizar el área inscrita en un programa de remoción de arbustos al enfocarse en propietarios de terrenos de mayor extensión, quienes parecen estar dispuestos a inscribir mayores porciones de sus tierras sin requerir una compensación que exceda el costo neto de la inscripción. Debido a que la tierra en la planicie Eduards esta siendo subdividida y comprada por gente que no depende de ingresos basados en estos terrenos y que pueden ser más tolerantes de los arbustos, los fondos públicos requeridos para motivar la participación de los propietarios pueden aumentar con el tiempo.

rapid population growth in rural areas combined with the declining profitability of traditional rural land uses are increasing rural land subdivision, resulting in $80 \%$ of Texas' farms and ranches now being smaller than 202 ha ( 500 acres) (Wilkins et al. 2000), and a shift from traditional to recreation-related land uses (Rowan 1994).

Continued recharge of aquifers and surface reservoirs is critical if the future water needs of this rapidly growing population are to be met. Because the rangelands of the Edwards Plateau are the primary catchments for the Edwards Aquifer and reservoirs upon which Austin, San Antonio and adjacent communities rely for water (Thurow and Thurow 1997), the future supply of water for 
the area will increasingly depend on the implementation of rangeland management practices that enhance water supply.

Plant communities in the Edwards Plateau have gradually changed from grasslands with a few scattered trees to woodlands (Smeins and Merrill 1988, Taylor and Smeins 1994, Smeins et al. 1997) dominated by live oak (Quercus virginiana Mill.), redberry juniper (Juniperus pinchotii Sudw.) and especially Ashe juniper (Juniperus ashei Buchh.) (Blackburn 1985, McGinty 1997). Because increase in woody plant canopies, especially juniper, can increase rainfall interception and evapotranspiration (Hibbert 1979, Thurow and Hester 1997), wider distribution and density of juniper has been associated with lower herbaceous production and water yields in the Edwards Plateau (Thurow and Hester 1997). While not the case everywhere (Wilcox 2002), some studies have documented elevated water yield following brush removal in the Edwards Plateau (Blackburn 1983, Hester et al. 1997, Thurow and Hester 1997, Dugas et al. 1998, Redeker 1998). In one case, reducing brush canopy cover from 30 to $3 \%$ reportedly resulted in a 10 -fold increase in water yield (Thurow et al. 1997). These findings combined with the favorable geohydrologic characteristics of the Edwards Aquifer catchment and recharge areas indicate that broad scale brush removal could enhance water yields (LCRA 2000).

In exploring alternatives for meeting water needs, the Texas Legislature has considered brush removal as 1 option for increasing water supplies (TWDB 1990). Accepting the inverse relationship between brush cover and water yields, it passed the Texas Brush Control Act for private lands in 1985 (TSL 1985), but no funds were immediately appropriated to implement the act due to limited evidence supporting this relationship in Texas (Griffin and McCarl 1989). Subsequent studies corroborating the relationship between brush cover and water yield in the Edwards Plateau (e.g., Thurow and Hester 1997) resulted in the passage of the omnibus water planning bill, ear-marking $\$ 10$ million for the Texas Water Assistance Program (TSL 1997). This appropriation recognized the importance of cost-sharing large-scale brush management because without financial support few landowners could afford to clear large areas of brush (Lee et al. 2001). Voluntary participation in a brush reduction program without cost-sharing is especially unlikely in semi-arid areas like the Edwards Plateau where the value of increased forage following brush clearing neither offsets the associated costs nor is it likely to offset the reduced income from hunting leases due to diminished wildlife habitat (Reinecke et al. 1997).

To determine the general feasibility of cost-share brush reduction programs for increasing off-site water yield, studies were initially conducted in 1998 for the North Concho River in West Central Texas (Bach and Conner 1998), and subsequently for 8 additional watersheds (TWRI 2000). To increase the probability of success of such programs, a high level of landowner participation is critical (Thurow et al. 2001). One survey of ranchers in the Edwards Plateau found that $66 \%$ of the respondents were willing to enroll in such a program (Garriga 1998). However, this study excluded small properties, which are becoming increasingly numerous on the Edward Plateau. Currently, little is known about the management objectives of smaller-property owners who frequently own their land more as a residence or for recreation than for production purposes. To gain a clear understanding of the factors influencing decisions of Edwards Plateau landowners to participate in brush reduction programs, randomized studies that include smallproperty owners would provide important new information.

Our study focused on landowners within or in close proximity to the Pedernales River basin, 1 of 8 watersheds for which the feasibility of a cost-share brush reduction program was analyzed (LCRA 2000, Bach and Conner 2001). Specifically, Blanco County (185,279 ha) and Gillespie County $(273,250 \mathrm{ha})$ were selected for the study because they contain a large range of property sizes. This was an exploratory study (rather than a study to test specific hypotheses), with 2 objectives: 1 . To understand landowner and brush cover characteristics in the study area, and 2. To identify factors influencing landowners' decisions to enroll in a cost-share brush management program, especially how property size affects landowner willingness to participate in such programs. Such knowledge is important for structuring a cost-share brush reduction program that has a high probability of adoption by landowners.

\section{Study Area and Methods}

The Pedernales River watershed is located in the Edwards Plateau, mainly in Blanco and Gillespie County, and it encompasses about 329826 ha (LCRA 2000). It is dominated by rangelands with extensive woody plant cover consisting mainly of junipers and oaks.

A mail survey of landowners in Blanco and Gillespie County was conducted in 2000. To obtain representative samples of landowners in both counties, mailing lists for $>4$ ha (10 acre) landholdings were obtained from both county appraisal offices. Properties less than 4 ha were excluded because the high per ha contract cost associated with very small landholdings would preclude them from a costshare program. Landholdings included in the mailing lists were stratified into 3 property-size categories: 4-20, 21-202, and $>202$ ha $(10-50,51-500$, and $>500$ acres, respectively). Samples of 120 landowners were randomly selected from each of the 3 property-size categories in each county, giving a total of 720 survey participants.

Pre-survey activities included a public information meeting in the study area, press releases in local newspapers, and information dissemination through Blanco and Gillespie County Extension Agents and Natural Resources Conservation Service (NRCS) representatives. One week before the survey questionnaire was mailed, a letter was sent to each selected landowner to explain the purpose of the study. The survey was conducted in June and July 2000 using Dillman's (2000) multi-contact procedure, with assurances of confidentiality. Because telephone numbers of survey participants were unavailable, follow up interviews with non-respondents were not conducted.

Survey participants were asked to provide responses only for land on which they pay property taxes in either Blanco or Gillespie County. Areas of inquiry in the questionnaire included landowner and property characteristics and landowner interest in participating in a cost-share brush reduction program. In this latter area of inquiry, participants were asked to estimate the proportion of their land covered by 4 generic categories of woody canopy cover (i.e., < 5\%, 5-25\%, 26-50\%, and > $50 \%$ ); and whether they would be interested in including "all", "none", or "part" of each (except the $<5 \%$ ) in a brush reduc- 
tion program. Some questions also asked survey participants to indicate their level of satisfaction with a particular aspect of brush management. A 1-5 Likert preference scale was used to determine the level of satisfaction, where 1 represented very dissatisfied, 3 indicated neutrality, and 5 represented very satisfied. As part of our study, we compared the responses of landowners who indicated they would be willing to enroll part or all of their land (prospective enrollees) in a brush reduction program with those who were not prepared to enroll any of their land (nonenrollees). In addition, differences in responses among landowners in the three property size categories were examined.

Response data were entered into a Microsoft Access database and analyzed using the Statistical Package for the Social Sciences (SPSS). Analysis of Variance (ANOVA) was used to test whether differences between sample means of continuous variables were statistically significant (e.g., differences in estimated brush cover or Likert scale evaluations among three property-size categories). Results of ANOVAs are presented by the sample means of variables being compared \pm the standard error of each sample mean, the ratio of mean squares $(F)$, and the probability $(P)$ of obtaining the $F$ ratio. When questions required the use of ordinal response categories, cross-tabulations and Goodman and Kruskal's Gamma $(\gamma)$ statistic (Norusis 2002) were used to determine the association between ordinal independent and dependent variables and whether these relationships were positive or negative (e.g, whether level of willingness to participate in a brush reduction program is positively or negatively associated with property-size categories). The results of tests of association of ordinal variables are reported by presenting the $\gamma$ value, followed the probability (P) of obtaining $\gamma$.

\section{Results}

Of the 720 questionnaires mailed, 418 $(58 \%)$ were returned with useable data: $30 \%$ were filled out by small-property owners (4-20 ha), 37\% by midsize-property owners (21-202 ha) and $33 \%$ by largeproperty owners (> 202 ha). The total acreage represented by the 418 landholdings was 82,641 ha, about $18.3 \%$ of the total area of Blanco and Gillespie Counties. Seventy eight percent $(n=328)$ of the respondents answered questions pertaining to their willingness to enroll at least part of their land with more than 5\% canopy cover in a cost-share brush reduction program. Of these, 268 respondents $(82 \%)$ indicated that they would likely enroll in such a program with 233 respondents indicating the proportion of their land they would enroll. These 233 respondents owned 40,662 ha of which they were willing to enroll 21,716 ha (53\%), but only 44 respondents representing 9,729 ha $(24 \%)$ said they would enroll "all" of their land.

\section{Respondent characteristics}

On average, respondents $(n=407)$ owned their land for $25.5 \pm 1.2$ years, but ownership period increased significantly with property size $($ small $=15.5 \pm 1.6$, midsize $=25.9 \pm 1.8$, large $=34.0 \pm 2.5$ years; $\mathrm{F}=20.10, \mathrm{P}<0.001)$. When asked about type of land ownership, respondents with multiple tracts of land could select more than 1 category. Individual ownership was selected by $76.4 \%$ of the respon- dents who answered this question $(\mathrm{n}=$ 416), followed by joint undivided interest or estate $(19.5 \%)$, partnerships $(8.4 \%)$, and other types of ownership $(7.2 \%)$, allowing most of them to make autonomous decisions about land management options and about participation in a brush reduction program.

About half the respondents $(n=410)$ lived on their land, but this declined with property size $($ small $=56.5 \%$, midsize $=$ $51.6 \%$, large $=44.4 \% ; \gamma=-0.157, \mathrm{P}=$ 0.050 ). Conversely, the residence time of respondents living on their land $(n=208)$ was positively related to property size $(\gamma=$ $0.534, \mathrm{P}<0.001$ ), with more small-property owners having lived on their land for 5 years or less $($ small $=35.7 \%$, midsize $=$ $15.2 \%$, large $=6.8 \%$ ) and more large- and midsize-property owners having resided on their land for more than 10 years (small $=42.9 \%$, midsize $=78.5 \%$, and large $=$ $83.1 \%$ ). The average age of respondents ( $\mathrm{n}$ = 398) also increased with property size $($ small $=56.0 \pm 1.0$, midsize $=60.5 \pm 1.2$, large $=64.8 \pm 1.1 ; \mathrm{F}=15.05, \mathrm{P}<0.001$ ).

When survey participants were asked to select the primary reason for owning their land, respondents $(n=414)$ most frequently selected source-of-income $(35.6 \%)$, followed by place-to-live $(27.7 \%)$, recreation (13.0\%), investment $(7.0 \%)$, multiple purposes $(8.7 \%)$ and other $(7.7 \%)$. Two of these reasons for ownership were strongly associated with property-size (Fig. 1). Source of income was positively associated with property size $(\gamma=0.719, \mathrm{P}<$ $0.001)$, while place to live was negatively associated with property size $(\gamma=-0.689$, $\mathrm{P}<0.001)$. Recreation as a reason for ownership also declined in importance with increase in property size $(\gamma=-0.229$, $P=0.046)$.

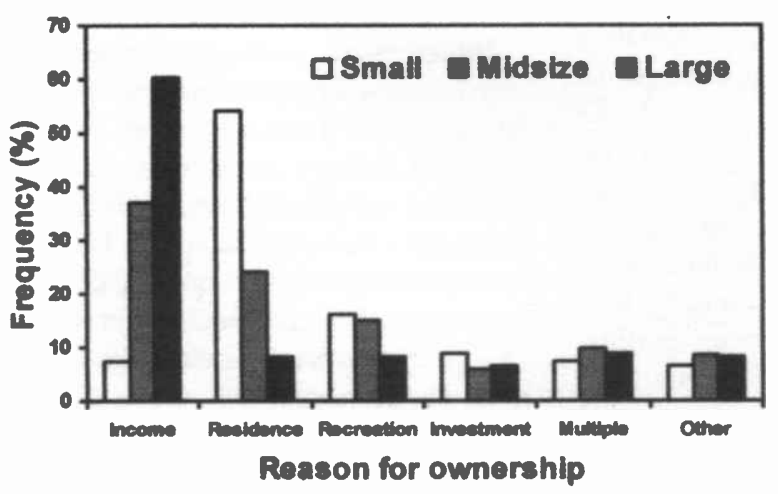

Fig. 1. Frequency with which small-, midsize-, and large-property landowners selected 6 primary reasons for owning their land (n: small $=124$, midsize $=154$, large $=136$ ) .

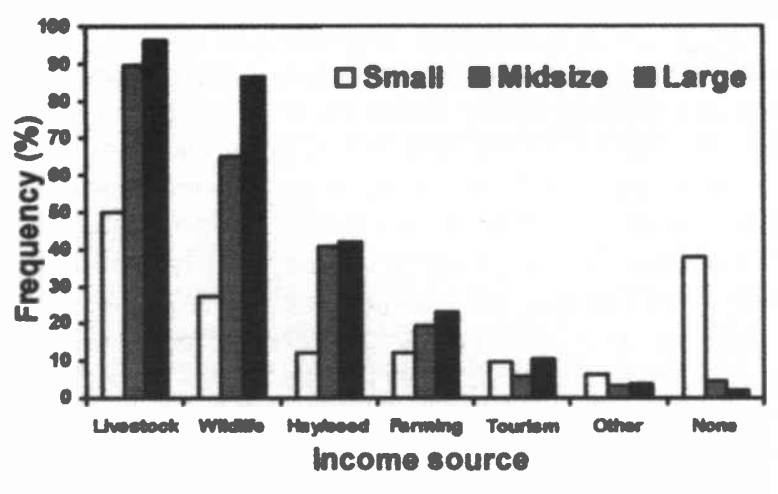

Fig. 2. Frequency with which land-based income sources were selected by small-, midsize-, and large-property landowners (n: small = 124, midsize $=150$, large $=133$ ). 
The finding that only about $35 \%$ of respondents owned their land mainly to earn income was consistent with the low level of income generated from their land. On average, respondents $(n=370)$ received only $16.8 \pm 1.3 \%$ of their annual household income from such activities, but this varied significantly among property-size groups. Large-property owners reported that they derived 4.5 times more of their income from land-based activities than small-property owners (small $=6.5 \pm$ 1.3 , midsize $=15.16 \pm 1.8$, large $=29.14 \pm$ $2.8 ; \mathrm{F}=30.16, \mathrm{P}<0.001)$.

Despite the widespread reliance on offproperty income, most landowners derived at least some income from their land. Overall, $79.6 \%$ of the respondents $(n=$ $407)$ reported receiving income from livestock, $60.7 \%$ from wildlife, $32.4 \%$ from hay/seed production, $18.4 \%$ from farming activities, $8.6 \%$ from nature tourism/recreation, and $4.4 \%$ from other non-agricultural activities, while $14.0 \%$ reported deriving no income from their land. However, the frequency of these income sources varied significantly between property-size groups (Fig. 2). Income from livestock, wildlife, hay/seed, and crop production were positively associated with property size (livestock $\gamma=0.805, \mathrm{P}<0.001$; wildlife $\gamma=0.717$, P $<0.001$; hay/seed $\gamma=$ $0.423, \mathrm{P}<0.001$; crops $\gamma=0.240, \mathrm{P}=$ 0.018 ), while significantly more smallproperty owners reported receiving no income from their land $(\gamma=-0.839, \mathrm{P}<$ 0.001 ).

To determine how best to disseminate information about potential cost-share brush management programs, survey participants were asked to identify the sources from which they obtain informa- tion about rangeland management. Overall, respondents $(n=396)$ most frequently selected Texas Cooperative Extension (TCE $=65.9 \%$ ), followed by other ranchers $(57.8 \%)$, and printed media $(56.3 \%)$, but a significantly greater proportion of midsize- and large-property owners use these sources than small-property owners (TCE $\gamma=0.325, \mathrm{P}<0.001$; printed media $\gamma=0.178, \mathrm{P}=0.028$; other ranchers $\gamma=0.165, \mathrm{P}=0.046 ;$ ). Texas Parks and Wildlife Department, Texas Department of Agriculture, and feed stores/coops were identified as information sources by $33-48 \%$ of the respondents, while the NRCS and the Internet were reportedly used by less than $25 \%$ of respondents, but more small-property owners $(26.7 \%)$ reported using the Internet than midsize- and large-property owners $(\gamma=-0.312, P=0.008)$.

\section{Brush cover and control}

Because landowners' perceptions about brush management may vary by dominant brush species, survey participants were asked to estimate the proportion of 5 vegetation cover types on their land. On average, respondents $(n=396)$ reported $36.5 \pm$ $1.2 \%$ herbaceous cover, $25.1 \pm 1.1 \%$ juniper, $24.1 \pm 0.9 \%$ live oak, $4.4 \pm 0.6 \%$ mesquite, and $9.9 \pm 0.7 \%$ other brush cover, and differences among propertysize categories were not significant.

Survey participants were also asked to indicate their level of satisfaction with the amount of these vegetation cover types on their land by using a 1-5 preference scale. Overall, $84.4 \%$ of the respondents $(n=$ $370)$ reported being satisfied $(4.25 \pm 0.05)$ with the amount of live oak and $61.3 \%$ of the respondents were satisfied (3.59 \pm
0.08) with the small amount of mesquite. In contrast, $71.7 \%$ of respondents were dissatisfied $(2.17 \pm 0.07)$ with the amount of juniper and $58.8 \%$ were dissatisfied $(2.54 \pm 0.07)$ with the amount of other brush on their land. Moreover, midsizeand large-property owners were less satisfied with the amount of mesquite ( $F=$ 5.83, $\mathrm{P}=0.003)$, juniper $(\mathrm{F}=3.77, \mathrm{P}=$ $0.024)$, and other brush $(\mathrm{F}=11.11, \mathrm{P}<$ 0.001 ) than small-property owners but they did not differ in their level of satisfaction with live oak cover. The differences in satisfaction with brush were in most cases directly related to the level of cover (Fig. 3). On average, landowners who were dissatisfied with the level of juniper, mesquite and other brush had significantly higher cover of these species than satisfied landowners $(P<0.001)$. These results suggest that, in general, respondents perceived juniper to be the most undesirable species, but they also preferred less mesquite and other brush. However, satisfied and dissatisfied landowners reported little difference in live oak cover possibly because the aesthetically attractive attributes of this species tend to elevate property values when present, suggesting that dissatisfied landowners may have preferred more rather than less live oak.

Because, water yields have been reported to increase when canopy cover declines, especially when cover drops below $15 \%$ (Thurow et al. 2000), landowners were asked to estimate the distribution of 4 generic woody-canopy cover categories on their land. Overall, respondents $(n=336)$ reported similar amounts of each category $(<5 \%$ cover $=25.4 \pm 1.3 \%, 5-25 \%$ cover $=$ $21.6 \pm 1.1 \%, 26-50 \%$ cover $=27.8 \pm 1.2 \%$,

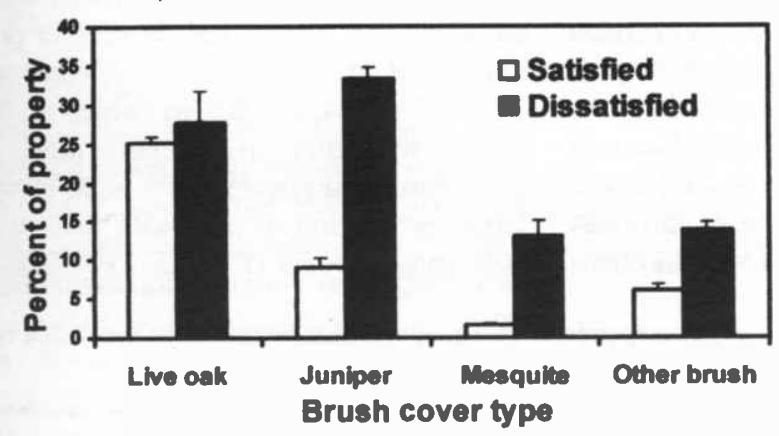

Fig. 3. Percent of land covered by mesquite, juniper, live oak, and other brush on the property of respondents who reported being satisfied or dissatisfied with the prevailing amount of brush on their land ( $n=$ satisfied, dissatisfied: live oak $=33,318$; juniper $=$ 94, 276; mesquite $=102,214$; other $=118,218$ ).

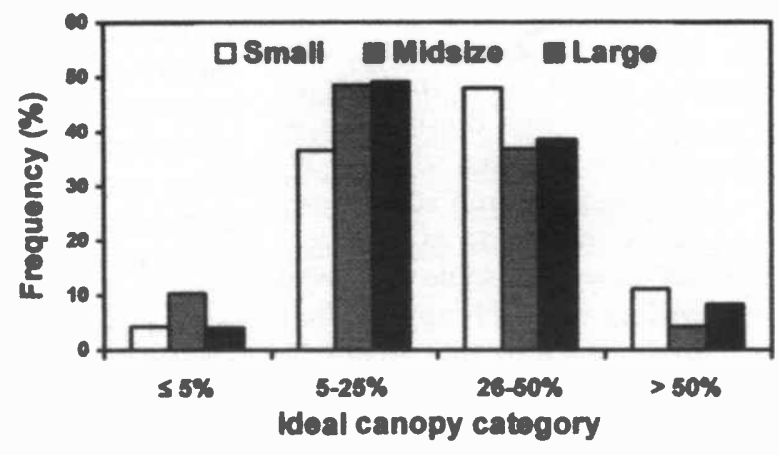

Fig. 4. Frequency with which small-, midsize-, and large-property owners selected one of four "ideal-canopy-cover" categories (n: small $=117$, midsize $=136$, large $=122$ ) 


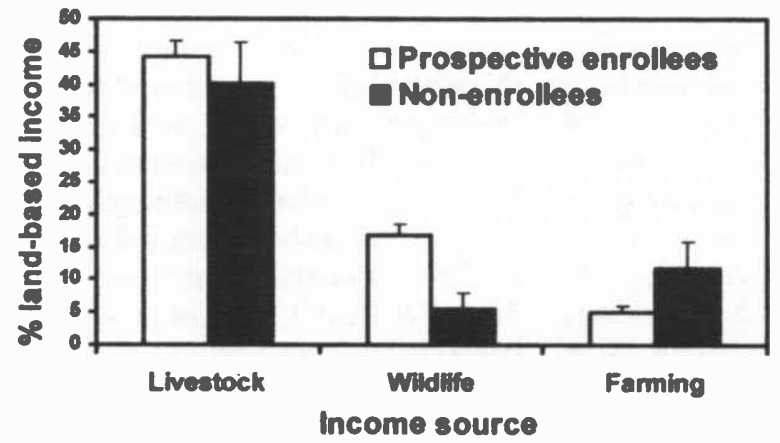

Fig. 5. Percent of land-based income derived from rangeland and agriculture-related activities by prospective enrollees $(n=268)$ and non-enrollees $(n=60)$.

$>50 \%$ cover $=25.2 \pm 1.4 \%$ ), and these proportions did not vary significantly among property-size categories. This suggests that about $75 \%$ of the study area, approximately 250,000 ha, would have to be incorporated in a brush reduction program to obtain relatively uniform brush cover of less than $5 \%$.

The extent to which such widespread brush treatment could be implemented is likely to depend on landowners' perceptions of the ideal percent canopy cover on their land. Survey participants were thus asked to select 1 of 4 canopy cover categories that best represented their ideal cover. Overall, $45.1 \%$ of the respondents $(\mathrm{n}=375)$ selected the $5-25 \%$ cover category, and $40.8 \%$ selected the $26-50 \%$ category. However, this preference varied with property size; about half of midsize- and large-property owners $(49.2 \%$ and $48.5 \%$, respectively) selected the $5-25 \%$ cover category as ideal, and a similar proportion of small-property owners (47.9\%) selected the $26-50 \%$ canopy cover as ideal $(\gamma=-$ $0.119, P=0.093$ ) (Fig. 4).

\section{Willingness to enroll}

Survey participants who responded to the question about their interest in enrolling in a cost-share brush management program $(n=328)$ and who indicated their willingness to enroll at least part of their land are referred to as "prospective enrollees" $(n=268)$, while those who were not willing to enroll any of their property are "non-enrollees" $(n=60)$. Willingness to enroll in a brush reduction program was positively related to property size $(\gamma=0.415, P<0.001)$ (Table 1$)$, with the average property size of the prospective enrollees $(214 \pm 19$ ha) being 2.4 times larger than that of non-enrollees (89 \pm 19 ha) $(F=9.22, P=0.003)$.

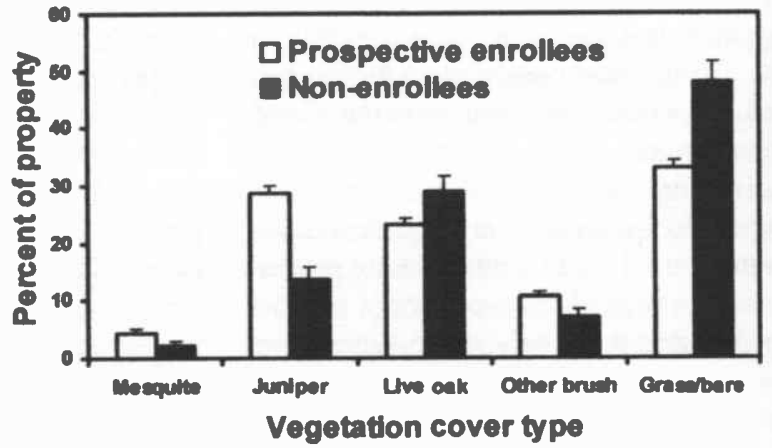

Fig. 6. Percent of land covered by mesquite, juniper, live oak, grasses/bare ground, and other brush on the property of prospective enrollees $(n=268)$ and non-enrollees $(n=60)$.
Two reasons for ownership of the land were also found to be associated with the degree to which respondents were willing to enroll. Of the respondents who selected source-of-income as the main reason for owning their property $90 \%$ indicated they were willing to enroll $(n=148$ of which $55 \%$ and $39 \%$ were large- and midsizeproperty owners, respectively) compared to $69 \%$ of respondents who selected placeto-live as the their primary reason for ownership ( $\mathrm{n}=115$ of which $58 \%$ and $32 \%$ were small- and midsize-property owners, respectively).

On average, prospective enrollees earned $17.4 \pm 1.4 \%$ of their total annual income from activities related to their land compared to $11.0 \pm 3.0 \%$ by non-enrollees $(\mathrm{F}=3.41, \mathrm{P}=0.066)$, neither group being economically dependent on their property. Although there was no significant difference between the proportion of prospective enrollees and non-enrollees who gained income from livestock $79.2 \%$ and $70.0 \%$, respectively), more prospective enrollees derived income from wildlife $(64.5 \%$ and $43.3 \%$, respectively, $\gamma=$ $0.408, \mathrm{P}=0.004)$. Similarly, while prospective enrollees and non-enrollees earned about the same proportion of their land-based income from livestock, prospective enrollees earned almost 3 times as much of their land-based income from wildlife compared to non-enrollees $(F=10.12, P=0.002)$, and non-enrollees earned proportionately more of their income from farming $(F=6.03, P=0.015)$ (Fig. 5). Note that the percentages presented in Fig. 5 do not sum to $100 \%$ because a large amount of "land-based" income in Texas is derived from mineral extraction.

The prevalence of vegetation cover type was also found to be associated with respondent willingness to enroll in a brush reduction program (Fig. 6). On average, percent cover of juniper and other brush was significantly greater $(\mathrm{F}=24.33, \mathrm{P}<$ $0.001 ; \mathrm{F}=3.86, \mathrm{P}=0.05$, respectively) and herbaceous cover or bare ground was significantly less $(F=17.98, P<0.001)$ on the land of prospective enrollees than nonenrollees. However, percent cover of live oak and mesquite did not differ significantly between them $(P=0.057$ and $P=$ 0.150 , respectively). This suggests that prevalence of juniper and herbaceous cover are the most influential vegetation type factors affecting landowners' willingness to enroll in a bush reduction program.

Landowner willingness to enroll was also found to be associated with the prevalence of overall brush densities (Fig. 7). Compared to non-enrollees, prospective enrollees had a significantly smaller proportion of their land with < 5\% canopy cover $(\mathrm{F}=5.64, \mathrm{P}=0.018)$ (which is consistent with their higher percentage of grass/bare land cover) and a significantly larger proportion of land with more than $50 \%$ canopy cover $(\mathrm{F}=8.57, \mathrm{P}=0.004)$.

Table 1. Overall willingness of survey respondents in 3 property-size categories to enroll in a cost share brush reduction program.

\begin{tabular}{lccc}
\hline \hline Property size category & Respondents & \multicolumn{2}{c}{ Willing to enroll } \\
\cline { 3 - 4 } & & Number & Percent \\
\hline $4-20$ ha & 108 & 79 & $73 \%$ \\
$21-202$ ha & 115 & 92 & $80 \%$ \\
$>202$ ha & 105 & 97 & $92 \%$ \\
\hline Total & 328 & 268 & $82 \%$ \\
\hline
\end{tabular}




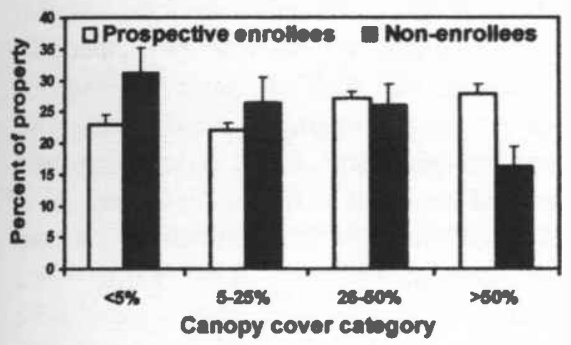

Fig. 7. Percent of land covered by each of four canopy-cover categories on the property of prospective enrollees $(n=268)$ and non-enrollees $(n=60)$.

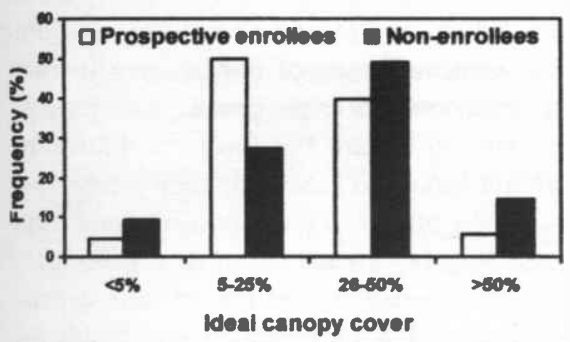

Fig. 8. Frequency with which prospective enrollees $(n=268)$ and non-enrollees ( $n=$ 60) selected 1 of 4 ideal-canopy-cover categories.

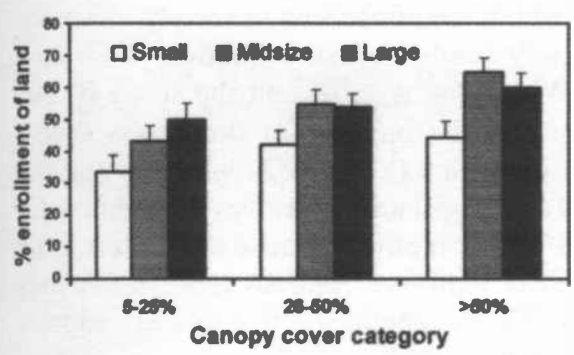

Fig. 9. Average potential enrollment of light (5-25\% cover), moderate ( $26-50 \%$ cover) and heavy ( $>50 \%$ cover) brush cover by small-, midsize-, and large-property owners ( $n$ : small $=73$, medium $=84$, large $=$ 76).

The proportion of intermediate canopy cover classes did not differ significantly between prospective enrollees and nonenrollees. Associated factors affecting respondents' willingness to enroll in a brush reduction program were their level of satisfaction with prevailing brush cover and the canopy cover considered to be ideal by survey participants. Based on the previously defined 1-5 preference scale, prospective enrollees were significantly less satisfied with the amount of brush on their property than non-enrollees $(2.78 \pm$ 0.06 and $3.65 \pm 0.15$, respectively; $F=$ $35.50, \mathrm{P}<0.001$ ). In addition, willingness to enroll and ideal canopy cover were inversely related; prospective enrollees most commonly selected $5-25 \%$ cover as ideal and non-enrollees favored $26-50 \%$ canopy cover $(\gamma=-0.272, P=0.037)$ (Fig. 8).

The extent to which prospective enrollees said they would enroll land with light (5-25\%), moderate (26-50\%) and heavy ( $>50 \%$ ) brush cover in a brush reduction program varied with property size (Fig. 9). Overall respondents $(\mathrm{n}=$ 233) indicated they would enroll $57.1 \pm$ $2.7 \%$ of the $>50 \%$ canopy cover areas, $50.1 \% \pm 2.6 \%$ of the $25-50 \%$ cover areas, and $42.4 \pm 3.0 \%$ of the $5-25 \%$ cover areas. However, midsize- and large-property owners indicated that they would enroll a significantly greater proportion of their land with $>50 \%$ brush cover $(\mathrm{F}=$ $4.81, P=0.009$ ), but the level of potential commitment for the other 2 canopy cover categories did not vary significantly among the three property size classes. The cumulative area that the respondents indicated they would enroll is presented in Table 2- Large-property owners indicated they would enroll the largest area of land $(82 \%)$ in a brush removal program, while small-property owners would contribute relatively little $(<2 \%)$.

The final area of inquiry was the extent to which prospective enrollees would be willing to use various brush reduction methods. This information is important for determining brush management constraints that might be imposed on a broad scale brush removal program. Ninety one percent of the prospective enrollees indicated that they would be willing to use mechanical treatments, $63 \%$ chemicallybased individual plant treatments, $53 \%$ fire, and $40 \%$ broadcast chemical treatments. While there were no significant differences among property size categories in the willingness to use mechanical treatments, large- and midsize property owners were significantly more willing to use chemically-based individual plant treatments $(F=13.84, P<0.001)$, and broadcast chemical treatments $(\mathrm{F}=3.02, \mathrm{P}=$
0.050 ), while midsize property owners were least willing to use fire as a brush management tool $(\mathrm{F}=6.70, \mathrm{P}=0.001)$.

\section{Discussion}

The ubiquitous increase in woody vegetation may be negatively affecting the capacity of rangelands in the Edwards Plateau to act as effective recharge catchments. Given that $95 \%$ of Texas is privately owned, it is imperative for a large number of landowners to participate if broadscale brush reduction is to be implemented. Many landowners in the Edwards Plateau appear to be reluctant to use prescribed fire or broadcast chemical treatments to manage brush, but appear to be more accepting of mechanical and chemically-based individual plant treatments. The Brush Busters program has played a leading role in increasing the adoption of select individual plant treatments (Kreuter et al. 2001), even though the direct benefits to landowners of using such treatments seldom offset their associated costs. Thus, public funding is likely critical if large numbers of landowners are to participate in broad scale brush reduction programs.

The results of our study support the conclusion of Thurow's et al. (2001) non-randomized rancher survey that a large proportion of landowners in the Edwards Aquifer area are willing to reduce brush reduction if sufficient public funds are provided to offset the net costs to the landowner. Overall, respondents to our survey indicated they would enroll slightly more than half of their land in a brush reduction program. Although this is less than the estimated $75 \%$ enrollment required to achieve < 5\% canopy cover, it nevertheless represents a large portion of their land. It is important to emphasize that most landowners would likely be selective in deciding which components of their land they would enroll. Unfortunately, these findings cannot be explicitly extrapolated to the whole Pedernales River watershed because we do not have data about the

Table 2. Potential enrollment (ha) of different canopy-cover categories by landowners in 3 property-size categories.

\begin{tabular}{lcccc}
\hline \hline Canopy cover & $4-20$ ha $(\mathrm{n}=63)$ & 21-202 ha $(\mathrm{n}=83)$ & $>202$ ha $(\mathrm{n}=87)$ & Total $(\mathrm{n}=233)$ \\
\hline $5-25 \%$ & 86 & 761 & 3,487 & 4,334 \\
$26-50 \%$ & 136 & 1,360 & 5,632 & 7,128 \\
$>50 \%$ & 134 & 1,534 & 8,586 & 10,254 \\
\hline Total & 356 & 3,655 & 17,705 & 21,716 \\
\hline
\end{tabular}


proportion of the watershed covered by each of the 3 property-size categories included in our study.

The average property size of respondents in our study who expressed interest in enrolling in a brush reduction program was 2.4 times as large as that of nonenrollees. Respondents with less than 20 ha, most of whom own their land mainly as a place of residence, were less inclined to participate than larger-property owners, many of whom reported owning their land mainly as a source of income even though land-based activities contributed relatively little to total income.

This difference was consistent with the finding that the small-property owners were generally more satisfied with the amount of brush on their land and preferred higher canopy cover than midsizeand large-property owners. The latter are more likely to reduce heavy brush cover $(>50 \%)$ if they participate in a brush reduction program because of their greater interest in forage production and wildlife habitat quality, both of which are diminished by heavy brush. This would be favorable for a brush reduction program aimed at increasing water yield because moderate and heavy canopy cover, especially of juniper, intercepts more precipitation than light canopy cover (Thurow and Hester 1997). The reluctance of smallproperty owners to participate in brush reduction indicates that there will likely be greater constraints for controlling brush in the future as land subdivision produces more small landholdings (Wilkins et al. 2000).

While the proportion of income earned by respondents from livestock was, on average, about two and a half times as much as that derived from wildlife, the proportion of wildlife-based income may be a more important determinant of landowners' willingness to enroll in a brush reduction program. The finding that, on average, prospective enrollees earned three times as much from wildlife as nonenrollees is interesting because excessive reduction in brush cover can adversely affect wildlife habitat. Although reduction in brush cover down to $5 \%$ was specified as a likely requirement of a brush removal program, the survey did not specify that landowners would have to include all of their land in the program. Selective thinning could have beneficial consequences for wildlife, especially white-tailed deer, but may not be optimal for water yield if landowners elect to maintain large proportions of dense brush.
Several policy implications emerge from our study. First, to ensure enrollment by a large proportion of landowners in brush reduction programs, sufficient funding must be provided to offset the net cost of brush reduction to landowners. As the number of small-property owners (who generally rely less on their land for income and who appear to be more tolerant of brush) grows, financial incentives over and above the cost of removing brush may be necessary to encourage them to reduce brush to a level that increases water yield but which may be below their preferred canopy cover. Additional funding may also be necessary to develop and disseminate educational messages to small-property owners about the importance of reducing brush cover and maintaining open rangelands.

A second policy question is what qualifying criteria should be used for landowner participation in a publicly supported brush reduction program aimed at increasing water yield. Historically, limited public funding has prevented the inclusion of all landowners in cost-share programs. To optimize public investments, it would be preferable to target property owners who are more willing to enroll substantial portions of their land without requiring compensation that exceeds their net cost of enrollment. Our study suggests landowners with more than 20 ha, who derive income from land-based activities (especially wildlife), and who have large portions of land with $>50 \%$ canopy cover appear to be better candidates than landowners with less land, who derive minimal or no income from their land, or who have less brush on their land. Per ha contract costs will be considerably less if fewer midsize- and large-property owners are targeted rather than numerous smallproperty owners. One solution to offset high contract associated with many smallproperty contracts could be to establish multi-owner "cooperatives" that use one brush-reduction contract.

A third issue to be addressed in developing and implementing a publicly funded brush reduction program is how best to disseminate information about the program. Because over two thirds of respondents with large- and midsize-properties indicated that they use TCE and printed media as information sources for rangeland management, these outlets would be important for ensuring effective information dissemination about brush reduction programs. Targeting key landowners from whom neighbors would take a lead is also likely to enhance landowner participation.

Finally, our findings have implications for policies relating to estate taxes and regional planning. High estate taxes and lack of regional planning have tended to promote ad hoc land subdivision and development (Wilkins et al. 2000). Since owners of smaller properties appear to be less interested in maintaining low brush cover, estate tax laws and poor development planning that exacerbate land subdivision could result in increasing resistance to brush clearing, thereby potentially negatively affecting future water supply from the Edwards Plateau. To maximize the economic efficacy of public investments in brush reduction programs, policy makers should ensure that larger landowners are not forced to subdivide their land.

While our study addressed questions regarding landowner interest in participating in a cost-share brush reduction program aimed at increasing water yields, in order to more thoughtfully allocate public funds for such programs, it did not quantify the dollar value of added water versus the cost of brush control. Therefore, it does not provide information about the overall benefit or loss to society of a publicly funded brush reduction programs. While this was beyond the scope of our study, the passage of the Texas Brush Control act (TSL 1985) indicates that the Texas legislature perceives the public benefits of such programs to exceed their costs. However, rigorous economic studies should be conducted to explicitly address this perception.

\section{Literature Cited}

Bach, J.P. and J.R. Conner. 1998. Economic analysis of brush control practices for increased water yield: The North Concho River example, pp. 209-217. In: R. Jenson, (editor) Proceedings of the $25^{\text {th }}$ Water for Texas Conference-Water planning strategies for Senate Bill 1. Austin, Tex.

Bach, J.P. and J.R. Conner. 2001. Pedernales River Watershed-economic analysis, pp. 14:1-8 In: Brush management/water yield feasibility studies for eight watersheds in Texas, Texas Water Resources Institute Tech. Rep. 182, Texas A\&M Univ., College Station, Tex.

Blackburn, W.H. 1983. Influence of brush control on hydrologic characteristics of range watersheds, pp.73-88. In: Proceedings of the brush management symposium. Soc. Range Manage. Albuquerque, N.M. 
Blackburn, W.H. 1985. Range improvements to maximize rainfall runoff, pp. 375-382. In: Proceedings of the International Ranchers Roundup. Laredo, Tex.

Conner, J.R. and L. James. 1996. Environment and natural resources: Trends and implications. Texas Agricultural and Natural Resources Summit on Environmental and Natural Resource Policy for the $21^{\text {st }}$ Century. Texas A\&M Univ., College Station, Tex

Dillman, D.A. 2000. Mail and internet surveys: The tailored design method. John Wiley and Sons. New York, N.Y.

Dugas, W.A., R.A. Hicks, and P. Wright. 1998. Effect of removal of Juniperus ashei on evapotranspiration and runoff in the Seco Creek watershed. Water Resources Res. 34:1499-1506.

Garriga, M.D. 1998. Tradeoffs associated with increasing water yield from the Edwards Plateau, Texas: balancing private costs and public benefits. M.S. Thesis. Texas A\&M Univ., College Station, Tex.

Griffin, R.C. and B.A. McCarl. 1989. Brushland management for increased water yield in Texas. Water Resources Bull. 25:175-186.

Hester, J.W., T.L. Thurow, and C.A. Taylor. 1997. Hydrologic characteristics of vegetation types as affected by prescribed burning. J. Range Manage. 50: 199-204.

Hibbert, A.R. 1979. Managing vegetation to increase flow in the Colorado River Basin. USDA Forest Ser. Gen. Tech. Rep. RM-66. Ft Collins, Colo.

Kreuter, U.P., H.E. Amestoy, D.N. Ueckert, and W.A. McGinty. 2001. Adoption of Brush Busters: Results of Texas county extension survey. J. Range. Manage. 54:630-639.

Lee, A.C., J.R. Conner, J.W. Mjelde, J.W. Richardson, and J.W. Stuth. 2001. Regional cost-share necessary for rancher participation in brush control. J. Agr. \& Resource Econ. 26:478-490.

LCRA (Lower Colorado River Authority). 2000. Pedernales River Watershed: Brush control assessment and feasibility study. URL: www.tsswcb.state.tx.us/reports/pedernales.pdf

McGinty, A. 1997. Juniper ecology, pp.13-22. In: Brush Sculptors: Innovations for tailoring brushy rangelands to enhance wildlife habitat and recreational value, Proceedings of a Conference. August 21-22, 1997. Uvalde, Tex.

Norusis, M.J. 2002. SPSS 11.0: Guide to data analysis. Prentice Hall, Upper Saddle River, N.J.

Redeker, E.J. 1998. The effects of vegetation on the water balance of an Edwards Plateau watershed: a GIS modeling approach. M.S. Thesis. Texas A\&M Univ. College Station, Tex.
Reinecke, R., J.R. Conner, and A.P. Thurow. 1997. Economic considerations in Ashe juniper control, pp.6: 3-10. In: Juniper Symposium 1997, Texas A\&M Univ. Res. Sta. Tech. Rep. 97-1. Sonora, Tex.

Rowan, R.C. 1994. Are small-acreage livestock producers real ranchers? Rangelands 16:161-166.

SAEDF (San Antonio Economic Development Foundation). 1999. San Antonio: A dynamic economy and culture. San Antonio, Tex. URL: http://saedf.dcci.com/xindex.html

Smeins, F.E. and L.B. Merrill. 1988. Longterm change in semi-arid grassland, pp.101-114, In: Edwards Plateau vegetation plant ecological studies in Central Texas. Baylor Univ. Press, Waco, Tex.

Smeins, F., S. Fuhlendorf, and C. Taylor. 1997. Environmental and land use changes: A long-term perspective, pp. 1:3-21. In: Juniper Symposium 1997, Texas A\&M Univ. Res. Sta. Tech. Rep. 97-1. Sonora, Tex.

Taylor, C.A. and F.E. Smeins. 1994. A history of land use of the Edwards Plateau and its effects on the native vegetation, pp. 1-8. In: Taylor, C.A. (ed.) Juniper symposium 1994. Texas A\&M Univ. Tech. Rep. 94-2, College Station, Tex.

TSDC (Texas State Data Center). 2000. Descriptive data tables from the 2000 census. In: Texas Population Estimates and Projection Program Database. Texas A\&M Univ., College Station, Tex. URL: http://www.txsdc.tamu.edu

TSL (Texas State Legislature). 1985. Sixtyninth legislature: Session logs. Chapter 655 , pp. 2409-2413. Austin, Tex.

TSL (Texas State Legislature). 1997. Seventy-fifth legislature: Session logs. Chapter 10-10, pp. 3610-3791. Austin, Tex.

TWDB (Texas Water Development Board). 1990. Water for Texas: Today and tomorrow. Document Number GP-5-1. Austin, Tex.

TWDB (Texas Water Development Board). 1997. Water for Texas: A consensus-based update to the state water plan. Document Number GP-6-2. Austin, Tex.

TWRI (Texas Water Resource Institute). 2000. Brush management/water yield feasibility studies for eight watersheds in Texas: Final Report. TWRI TR-182, BRC Report 01-01. Texas A\&M University, College Station, Tex.

Thurow, T.L. and J.W. Hester. 1997. How an increase or reduction in juniper cover alters rangeland hydrology, pp. 4:9-22. In: Juniper Symposium 1997, Texas A\&M Univ. Res. Sta. Tech. Rep. 97-1. Sonora, Tex.

Thurow, T.L. and A.P. Thurow. 1997. Juniper Management in the Edwards Plateau: Policy issues and options, pp. 80-92. In: Juniper Symposium 1997, Texas A\&M Univ. Res. Sta. Tech. Rep. 97-1, Sonora, Tex.
Thurow, T.L., A.P. Thurow and M.D. Garriga. 2000. Policy prospects for brush control to increase off-site water yield. J. Range Manage. 53:23-31.

Thurow, A.P., J.R. Conner, T.L. Thurow, and M.D. Garriga. 2001. A preliminary analysis of Texas ranchers' willingness to participate in a brush control cost-sharing program to improve off-site water yields. Ecol. Econ. 37:139-152.

Thurow, T.L., A.P. Thurow, C.A. Taylor, J.R. Conner, and M.D. Garriga. 1997. Environmental and economic tradeoffs associated with vegetation management on the Edwards Plateau, pp. 2:3-9. In: Juniper Symposium 1997, Texas A\&M Univ. Res. Sta. Tech. Rep. 97-1. Sonora, Tex.

Wilcox, B.P. 2002. Shrub control and streamflow on rangelands: A process-based viewpoint. J. Range Manage. 55: 318-326.

Wilkins, N., R.D. Brown, J.R. Conner, J. Engle, C. Gilliland, A. Hays, R.D. Slack, and D.W. Steinbach. 2000. Fragmented lands: Changing land ownership in Texas. Technical booklet 15M 9/00, Texas A\&M Univ. College Station, Tex. 